\title{
The role of aquaria in beluga research and conservation
}

\author{
Tracy A. Romano ${ }^{1}$, Laura A. Thompson ${ }^{1}$, Maureen V. Driscoll1 ${ }^{1}$, Ebru Unal' ${ }^{1}$, Allison D. Tuttle ${ }^{2}$, \\ Gayle Sirpenski ${ }^{2}$, Mary Ellen Mateleska ${ }^{3} \&$ Dale Wolbrink ${ }^{4}$ \\ ${ }^{1}$ Mystic Aquarium, Research Dept., Mystic, CT, USA; \\ ${ }^{2}$ Mystic Aquarium, Zoological Operations, Mystic, CT, USA; \\ ${ }^{3}$ Mystic Aquarium, Education and Conservation, Mystic, CT, USA; \\ ${ }^{4}$ Mystic Aquarium, Public Affairs, Mystic, CT, USA
}

\begin{abstract}
Aquaria that care for and maintain belugas (Delphinapterus leucas) under professional care have the opportunity to contribute to the conservation of wild belugas through research, expertise in animal care and husbandry, and engaging and educating the public about threats to the species' health and population sustainability. In an aquarium setting, belugas can be studied under controlled conditions, with known variables that are often difficult to discern when studying wild belugas. Information on nutrition, health status and environmental parameters can be easily obtained in a controlled setting. Biological samples are collected from professionally trained whales that voluntarily participate in informative experimental paradigms. Research studies in aquaria seek to contribute to the recovery and management of endangered beluga populations, such as those in Cook Inlet. Mystic Aquarium's efforts are presented as a case study. Key research priorities address action items in the Cook Inlet Beluga Recovery Plan and include: (1) understanding the beluga immune system, microbial communities, pathogens and disease; (2) development of non-invasive methods for assessing reproductive status, body condition and health in wild whales; (3) investigation of diving physiology and the impact of altered dive patterns on health; (4) understanding reproduction, a key to recovery and sustainability of wild populations; (5) development and testing of new technologies for tracking and monitoring whales and habitat use; and (6) understanding how noise affects beluga hearing, behaviour and physiology. Expertise in animal handling, behaviour and nutrition contribute to rescue, rehabilitation and capture release efforts. Moreover, 'students' of all ages have the opportunity to be engaged, educated and contribute to beluga conservation.
\end{abstract}

This article is part of the special cluster Beluga whales (Delphinapterus leucas): knowledge from the wild, human care and TEK, which has been funded by Mystic Aquarium, CAFF and the Norwegian Ministry of Climate and Environment

\section{Introduction}

Climate change, oil and natural gas activities, commercial shipping, oil spills, mining for minerals and other human activities are affecting Arctic ecosystem health and pose significant threats for its future, including the animals and people that live there. Belugas (Delphinapterus leucas) inhabiting Arctic and Subarctic regions are no exception. It is unclear what effects climate change will have on belugas; however, with the loss of sea ice comes more opportunity for anthropogenic threats. Increased

\section{Keywords}

education; husbandry; whales; recovery and management; Delphinapterus leucas, zoos

\section{Correspondence}

Tracy A. Romano, Mystic Aquarium, Research Dept., 55 Coogan Blvd., Mystic, CT 06355, USA. E-mail: tromano@ mysticaquarium.org

\section{Abbreviations}

AEP: auditory evoked potential CIBRP: Cook Inlet Beluga Recovery Plan NMFS: US National Marine Fisheries Service NOAA: US National Oceanic and Atmospheric Administration NSB-DWM: North Slope Borough Department of Wildlife Management, Alaska UAV: unmanned autonomous vehicle UConn: University of Connecticut shipping traffic not only increases potential collision and injury to whales, but also exposes them to increasing sound levels and pollution. The same is true for mining, offshore oil and gas exploration, drilling and scientific exploration. Predator-prey relationships may shift with changes in water temperatures; predators such as killer whales (Orcinus orca) may become a more common threat to belugas and/or prey availability and distribution may be altered with the changing water temperatures. Emerging pathogens threaten health and can be especially detrimental to smaller populations of belugas. 
Oil spills and contaminants threaten entire ecosystems. A combination of these stressors or cumulative effects of multiple stressors on beluga populations may occur with harmful effects particularly on smaller populations (Ford et al. 2006; Burek et al. 2008; Moore \& Huntington 2008; Kovacs et al. 2011).

Belugas in aquaria are important ambassadors for wild whales and aquaria have an opportunity to connect the public with whales in the Arctic. Previous research has indicated that large, charismatic megafauna (such as belugas) have the potential to positively influence the public's connection and behaviour towards conservation for individual species and biodiversity in general (Skibins et al. 2013). Specifically, aquaria can contribute to the public's general knowledge of beluga conservation with programming highlighting their (1) research, (2) expertise in animal care and husbandry and (3) education/ outreach.

The purpose of this perspective paper is not an exhaustive review of contributions of aquaria to date but to raise awareness to beluga stakeholders (including, but not limited to, wildlife biologists, subsistence hunters, academics, non-governmental organizations, federal and state managers and policy-makers) of the capabilities and opportunities for utilizing belugas in aquaria. We also aim to demonstrate how key questions about belugas can be more easily answered by studying these whales in aquaria versus in the wild, thereby contributing to research on, and the recovery and conservation of, belugas worldwide. We highlight the efforts of Mystic Aquarium, CT, USA, as a case study to demonstrate how aquaria can provide vital scientific information and also make an indirect impact to marine mammal conservation through outreach to the general public.

\section{Why research with aquarium whales?}

Aquaria offer opportunities for controlled studies that are not feasible in the field with wild whales. In the aquarium setting, information is known about individual animals, including age, sex, life history, growth and reproductive stage, diet, blubber thickness throughout four seasons, morphometrics (e.g., weight, length and girth), health history and current health status. Most of this information is not consistently available from wild whales. Moreover, animal husbandry personnel who daily care for, train and do other work with the whales, know each individual's normal behavioural repertoire and can recognize when behaviour or appetite, for example, may be abnormal. Environmental parameters, such as air and water temperature and water chemistries, are also known. Capture-release studies can collect a great deal of information from wild whales; however, samples are usually from a single point in time and some of the health indices, such as complete blood cell counts and serum chemistries, may reflect physiological states associated with the chase and capture, confounding results.

The second major advantage of studying whales under professional care in aquaria is that whales can be trained for biological sampling. Through operant conditioning with positive reinforcement (Ramirez 1999; Kuczaj \& Xitco 2002; Brando 2010), whales voluntarily participate in biological sample collection for health-care monitoring and research. The training process allows for the collection of blood, breath, saliva, urine, faeces and skin scrapings as well as ultrasound and endoscopic examinations. These samples provide baseline reference values for individual and group animal health and include complete blood cell counts, serum chemistry panels, hormones, immune function, gene expression and exposure to pathogens, among other information. Moreover, these samples provide a reference to aid in the interpretation of values from wild captured-released whales, subsistence-hunted whales and free-swimming whales. As tools to better understand animal health continue to develop (Unal et al. 2018; Van Cise et al. 2020; Unal \& Romano 2021), archived samples are a valuable resource for future studies, e.g., preserved DNA/RNA samples to detect pathogens or to apply genomic or transcriptomic technologies.

In addition to biological sampling, whales in aquaria are trained to participate in experimental paradigms. These paradigms, similar to biological sampling, are always achieved through operant conditioning with positive reinforcement and occur only by voluntary participation of the whales. Examples of experimental paradigms include belugas stationing at the surface (with their blowhole exposed to air) to allow the placement of suction cup electrodes on the body (whereby auditory brainstem responses are measured for acoustic studies) and stationing at a certain depth for a determined amount of time, followed by surfacing and exhaling for breath collection (for diving physiology studies). Whales can be trained for even more complex experimental paradigms. Importantly, data are collected without confounding variables (e.g., ship disturbance, nutritional factors, nearby predators) that may be present when studying wild whales.

\section{Case study: Mystic Aquarium}

Established in 1973, Mystic Aquarium is accredited by the Association of Zoos and Aquariums, the Alliance of Marine Mammal Parks and Aquariums and the International Marine Animal Trainers' Association and is certified by American Humane, a national animal 
welfare organization, for maintaining the highest standards in animal care, training and welfare. The mission of Mystic Aquarium is to "inspire people to care for and protect our ocean planet through conservation, education, and research".

Early beluga studies at the aquarium were pioneered by the late David St. Aubin, a renowned figure in the field of beluga research and biology (Fig. 1). Beluga research-in the aquarium setting (ex situ) and in the field (in situ)_continues to be a major focus of the facility's research programme. Mystic Aquarium has a research license issued by the US Department of Agriculture to conduct research on its animal collection and a well-established Institutional Animal Care and Use Committee. It also has a team of research scientists, animal care and husbandry experts, and veterinarians who contribute to the research. Its research scientists all have joint appointments in the Department of Marine Sciences, UConn, where Mystic Aquarium's state-of-theart research laboratories are located. To expand expertise and scope, the aquarium works with a formal network of scientists (known as scientists-in-residence) as well as a Research Advisory Council that provides recommendations for, and serves as a resource to benefit, the research programme.

Mystic Aquarium contributes to conservation-related research of belugas by endeavouring to answer specific hypothesis-driven questions related to health about the whales under professional care as well as through field studies of wild belugas. Moreover, the aquarium's research addresses action items called for in the CIBRP (NMFS 2016), a conservation plan for belugas in Cook Inlet, AK. Examples of questions and corresponding action items addressed in the CIBRP include, but are not limited to, the following: (Question) "How does anthropogenic noise such as pile driving and shipping noise affect hearing and physiology in belugas"? (Action \#30) "Describe the acoustic characteristics of different anthropogenic noise sources in Cook Inlet and rate the potential acoustic impacts from each type of noise source on Cook Inlet belugas". (Question) "How does physiology

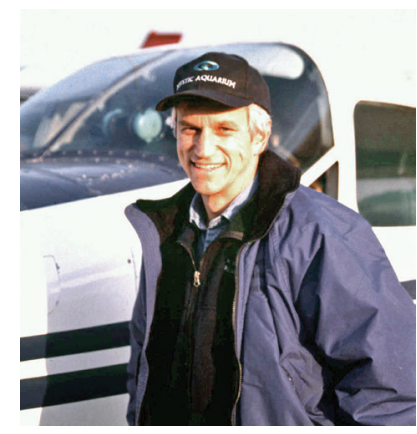

Fig. 1 Dr David St. Aubin (19522002), renowned for his research and contributions to beluga biology, was the Director of Research and Veterinary Services at the Mystic Aquarium from 1993 to 2002. change when beluga dive patterns are altered or interrupted by anthropogenic activities?" (Action \#45) "Refine research techniques, evaluate alternatives, and implement research methods which minimize harassment, harm, and general adverse impacts on Cook Inlet belugas". (Question) "Can gene expression changes be measured and monitored in beluga skin through remote biopsy in relation to environmental change?" (Action \#4) "Increase efforts to identify and monitor individual Cook Inlet belugas, coordinating photo-identification, stranding data, genetic studies, and body condition assessments via biopsy samples of skin and blubber" and (Action \#6) "Conduct regular biopsy surveys of Cook Inlet belugas to monitor changes in condition and reproductive success in relation to environmental changes".

Additional questions linked to action items in the CIBRP are incorporated in the research studies described below. The studies focus on health, diving physiology, reproductive biology, habitat monitoring and testing of prototype telemetry devices and cameras, hearing and physiological responses to anthropogenic sound, and photogrammetry, and they illustrate how research on Mystic Aquarium belugas informs the management and conservation of wild belugas.

\section{Health assessment and monitoring: developing assays and reagents as a toolbox for assessing beluga health}

There is a need for cetacean-specific reagents and assays to assess certain aspects of health as immune system function, microbial flora, pathogen exposure, stress, reproductive and metabolic hormones and cellular responses at the molecular level. Some of the first studies characterizing the cetacean immune system, for example, were made possible through the cooperation and support of native subsistence hunters, who made lymphoid organs available to researchers from their beluga harvest (Romano et al. 1993, 1994; Romano et al. 2002). It soon became clear that cetacean-specific assays, reagents, markers and molecular probes were needed to further investigate this and other health indices. Through the continued opportunity to collect tissues from subsistence-hunted belugas and to obtain blood samples from belugas and bottlenose dolphins (Tursiops truncatus) in aquaria, specific reagents and assays were developed, adapted and standardized to assess immune function and health (Romano et al. 1992; DeGuise et al. 1997; Romano et al. 1999; DeGuise et al. 2002; Mancia et al. 2007; Keogh et al. 2011; Spoon \& Romano 2012). In addition, marine mammal-specific diagnostic assays were developed to detect disease and pathogens such as Brucella, a bacterium 
that can cause reproductive failure in marine mammals (Meegan et al. 2010; Meegan et al. 2012).

This ever-evolving toolbox contributes to health assessments and monitoring for both aquaria-managed and free-ranging (including wild captured-released and subsistence-hunted) belugas. Health monitoring of different beluga populations is important for people consuming belugas for food and has been, and continues to be, applied to the subsistence-hunted whales and findings reported to the Alaska Beluga Whale Committee as opportunities warrant. Moreover, applying this toolbox to wild captured-released belugas in Bristol Bay, AK, and the Chukchi Sea is allowing for health monitoring over time and improves our understanding of the impact of environmental and anthropogenic stressors on individual whales and populations (Fair et al. 2013; St. Aubin et al. 2013; Flower et al. 2015; Unal et al. 2018; Bossart et al. 2019). The information gained through the development and validation of health-related reagents and assays facilitates interpretation of health measurements and biomarkers in wild whales. Continued diagnostic assay development and validation for microbial communities, pathogens and disease agents applies to CIBRP Action \#25- “Compare data on diseases from Cook Inlet belugas with other beluga populations to determine if there are abnormal levels or atypical types of disease agents present in Cook Inlet affecting Cook Inlet belugas". Hand in hand with pathogen exposure is immune system function and comparing immune status of Cook Inlet belugas with other beluga populations, which will indicate if Cook Inlet belugas are immunocompromised. These studies will help reveal the types of disease agents specific to each population, including Cook Inlet belugas, and will contribute to CIBRP Action \#26- “Determine types and sources of disease agents identified to be of concern specifically to Cook Inlet belugas and assess management actions targeted at mitigating the disease agents". Once the pathogens are identified, sources can be investigated and mitigation management actions can be put into place.

\section{Health assessment and monitoring: neuroimmunological response to environmental and anthropogenic stressors}

It is now generally accepted that stressors as perceived by the nervous system, can affect the immune system and an organism's ability to fight off disease and infection (Tausk et al. 2008). Tissues from subsistence-hunted belugas enabled identification of an anatomical link between the nervous and immune systems in the beluga (Romano et al. 1994; Romano et al. 2002), whereby hormones and neurotransmitters released during response to a stressor(s) could have an effect on the immune system and the animal's ability to fight off infection and disease. However, very little is known about the stress response in cetaceans, let alone the immune system. Knowledge in both regards is important for understanding how different anthropogenic and environmental stressors impact health in belugas and cetaceans in general.

In order to study the physiological response to stressors and impact on the immune system, Mystic Aquarium conducts controlled studies on belugas under professional care, subsistence-hunted belugas and wild capturedreleased cetaceans. Examples include, but are not limited to, studies addressing the physiological response to sound, transport, introduction to novel environments and chase, capture and restraint (Romano et al. 2004; Bossart et al. 2008; Reif et al. 2009; Schmitt et al. 2010; Spoon \& Romano 2012; St. Aubin et al. 2013; Fair et al. 2014; Thompson et al. 2014; Fair et al. 2017; Unal et al. 2018). Taking advantage of opportunistic events in the aquarium setting, such as out-of-water clinical examinations or procedures, transport and introduction to new social groups, enables the study of the hormones released, their timing, duration and magnitude (Schmitt et al. 2010; Spoon \& Romano 2012; Unal \& Romano 2021). These measures in response to known 'stressors' serve as reference for values obtained in wild whales and enables the characterization of stressors on a scale given the physiological response (for example, levels of stress hormones observed after controlled exposures to impulsive sound are less than levels observed in stranded cetaceans [Romano et al. 2004; Romano unpubl. data]).

Measurements obtained from aquarium belugas can provide a frame of reference for similar measurements in wild whales, aiding in the interpretation of data from wild captured-released belugas, subsistence-hunted belugas or biological samples obtained remotely from wild whales, e.g., skin biopsies, breath, faeces and enable pinpointing immune function differences both between and within populations. In addition, signals of temporal, spatial and seasonal change for health-related biomarkers (e.g., hormones, gene expression) are also obtainable from aquarium belugas. Hormone, immune and other health-related data are currently being analysed by Mystic Aquarium scientists, who are working with blood, skin, breath, faeces and other material from belugas, including endangered belugas (Cook Inlet and St. Lawrence Estuary belugas). The researchers will compare these to aquarium whales to potentially reveal health deficiencies in endangered wild populations due to pollutants, microbes, and/or stressors that can potentially be mitigated with management practices. In addition to Actions \#25 and \#26, referred to earlier, this effort contributes to CIBRP Actions \#4 and \#6: “Increase efforts to identify and monitor individual Cook Inlet 
belugas, coordinating photo-identification, stranding data, genetic studies, and body condition assessments via biopsy samples of skin and blubber" and "Conduct regular biopsy surveys of Cook Inlet belugas to monitor changes in condition and reproductive success in relation to environmental changes".

\section{Health assessment and monitoring: developing novel non-invasive techniques}

Blood is often a 'gold standard' for measuring certain health indices in animals (and people), but extracting it requires handling and restraint, unless the animal is trained to allow sample collection. However, blood cannot be obtained from wild belugas without capture, an event that can cause changes in the very hormones and other health indices that researchers seek to measure.

Mystic Aquarium scientists continue to develop and validate assays for detecting hormones, immune and transcriptional activity in saliva, breath, faeces and skin as alternatives to blood (Thompson et al. 2014; Flower et al. 2015; Richard et al. 2017; Unal et al. 2018). Development of these techniques is only possible by obtaining samples on a regular basis from aquarium whales for laboratory and biological validation (Fig. 2). The goal is to transition these less invasive techniques to free-ranging belugas, as has been done in other cetaceans (Rolland et al. 2005; Acevedo-Whitehouse et al. 2010; Hunt et al. 2013; Apprill et al. 2017). Testing how breath samples are collected under controlled conditions, for example, will help determine the number of breaths needed to detect a hormonal or molecular signal and how high the collecting device needs to be above the blowhole and has the potential to improve the methodology for collecting (with drones or poles) samples from wild whales.

These novel non-invasive techniques may be useful for controlled sound exposure studies to more effectively study the impacts of noise pollution. During hearing studies, for example, instead of having to halt recordings of non-invasive AEPs to obtain a blood sample (Romano et al. 2004), a breath sample may be easily and efficiently collected while an animal remains in the hearing study layout position, reducing interference with the hearing study and reflecting more immediate measurements specific to the noise exposure. Sound limits of different anthropogenic noises (e.g., pile-driving, ships, etc.) can be determined based not only on the whales' auditory response but also on other physiological responses and reported to wildlife managers and environmental policy-makers. The development of non-invasive techniques for assessing and monitoring health in belugas contributes to CIBRP Actions \#4, \#6 and \#45: "Increase efforts to identify and monitor individual Cook Inlet belugas, coordinating photo-identification, stranding data, genetic studies, and body condition assessments via biopsy samples of skin and blubber"; "Conduct regular biopsy surveys of Cook Inlet belugas to monitor changes in condition and reproductive success in relation to environmental changes" and "Refine research techniques, evaluate alternatives, and implement research methods which minimize harassment, harm and general adverse impact on Cook Inlet belugas".

\section{Dive physiology}

Altered dive behaviour in response to anthropogenic activity and noise has also been reported in cetaceans. Bottlenose dolphins (Lusseau 2003) and humpback whales (Megaptera novaeangliae; Corkeron 1995; Schaffar et al. 2009) increased dive behaviour in the presence of whale-watching boats, while beaked whales (Ziphius cavirostris) have displayed 'unusual' foraging dives and altered characteristics of dive ascent and post-dive interval following exposure to ship noise (Aguilar Soto et al. 2006) and sonar (Tyack et al. 2011). These and other anthropogenic activities may serve as stressors (Fair \& Becker 2000; Tarlow \& Blumstein 2007) interrupting dives as well as adaptation mechanisms used in diving, leaving cetaceans more susceptible to injury and disease. While this has been documented in other cetacean species,
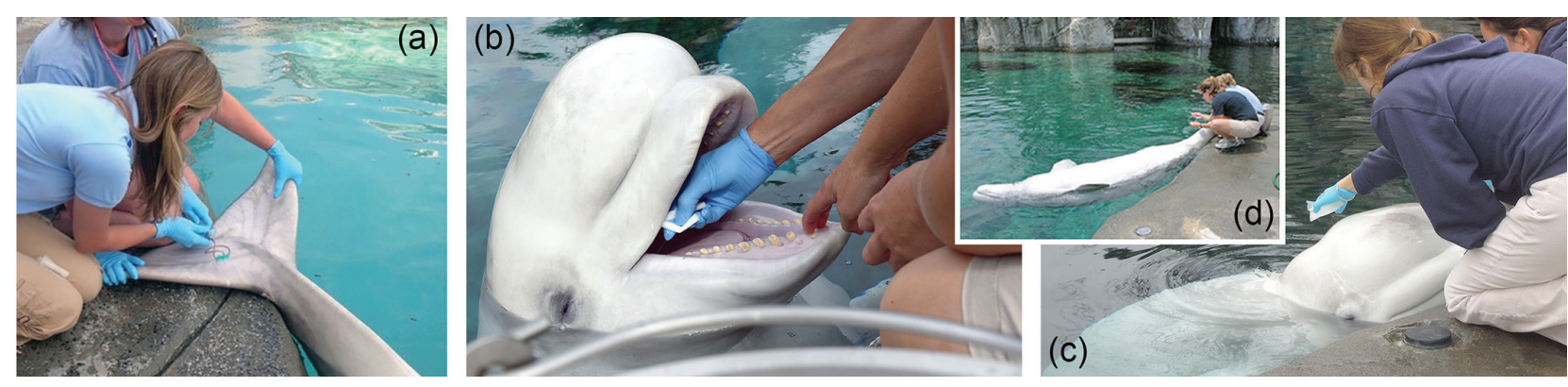

Fig. 2 Belugas are trained for (a) blood, (b) saliva, (c) breath and (d) faecal collection through operant conditioning with positive behavioural reinforcement. 
little information is available on belugas. Avoidance behaviours, including diving, have been observed in belugas' response to the presence of large ships, such as icebreakers (Richardson \& Wursig 1997), and small boats (Thompson, pers. obs. 2014, 2016). Environmental changes, such as warming surface waters related to climate change are also reportedly leading to some beluga populations making deep (>1000 m) and extended (>20 minutes) dives more often (Hauser 2016; Hauser et al. 2018). This has highlighted the need to understand the relationship between health and diving physiology in belugas, and the potential impact of altered dive behaviour on health in response to human activities, e.g., shipping, and the changing environment. Data from these studies could contribute information to set limits and restrictions on shipping, including designated times of the year ships are allowed in certain areas, duration, shipping routes and lanes, ship speeds, etc.

Mystic Aquarium scientists are studying how marine mammal immune cells function during diving and how additional stressors may alter this function, influencing marine mammal health. Beluga blood samples can be exposed to simulated dives using a pressure chamber and the responses of immune cells to changes in pressure measured (Thompson \& Romano 2015, 2016). Blood and breath samples are also obtained from aquarium whales after active dives (dives including swimming underwater from point $\mathrm{A}$ to point $\mathrm{B}$ to point $\mathrm{C}$ ) versus stationary dives (stationing on a target at depth) to determine the influence of breath-hold and activity level on response of the immune system during diving (Thompson \& Romano 2021 [this special cluster]).

Insight into the relationship between diving and health, via immune responses, will allow us to better interpret the effect of a changing Arctic environment on belugas. For example, some beluga populations are making deep and extended duration dives more often, likely to reach prey in deeper waters (Watt et al. 2016; Hauser et al. 2018). If such activities are pushing animals to, or beyond, their physiological limits more and more often, the risk of immune dysfunction and, therefore, injury or disease may be increased. Additionally, the impact of a sudden change in behaviour in response to human activity (e.g., loud noise), combined with the simultaneous acute physiological stress response, on immune function is unknown.

Consideration of how these altered behaviours relate directly to immune function and health can inform management decisions involving resources such as commercially valuable prey species or regulating human activity in biologically important habitats. If belugas are already immune-compromised, it is important to know whether routine dive behaviours then become more challenging and leave animals more susceptible to injury or disease. For example, in Cook Inlet, which is not a deep-water habitat, belugas may change the duration of dives or inter-dive intervals in response to potential stressors, such as ship traffic. At Mystic Aquarium, the relationship between dive duration and immune function can be investigated under controlled conditions with belugas that are trained to dive. While much more work is needed to describe the response of immune cells to the natural challenges of diving, so that we can then evaluate the impact of unusual behaviour on whales, aquariums offer a unique resource for both in vitro and in vivo studies. By investigating diving physiology under controlled conditions on aquarium whales with known diving parameters and conditions and/or simulating dives (exposing blood cells to pressure in vitro) and determining changes in cellular response (see Thompson \& Romano 2021), these diving studies contribute to CIBRP Action \#45-“'Refine research techniques, evaluate alternatives, and implement research methods which minimize harassment, harm, and general adverse impacts on Cook Inlet belugas".

\section{Reproductive biology}

Harsh environmental conditions, the seasonal nature of when whales can be observed and the high costs of getting to the whales and conducting field research make observing beluga behaviour in the wild extremely difficult. It is especially difficult to observe reproductive behaviours in wild belugas and virtually impossible to pair reproductive behaviour with physiological measurements in wild belugas. We do not know the beluga reproductive behavioural repertoire, including the courtship sequence, vocalizations, how belugas signal interest, receptiveness and readiness to mate with potential partners, and how mate choice is expressed or exerted. It is also unknown how courtship behaviours influence hormonal staging for reproduction and pregnancy and how hormonal state influences courtship and reproduction behaviour.

Aided by the aquarium's Arctic Coast habitat layout and the large underwater viewing windows, Mystic Aquarium's scientist-in-residence, Justin Richard, is addressing these knowledge gaps by observing behaviour and recording vocalizations before, during and after the breeding season and tying those behaviours to reproductive status, as indicated by hormones and ultrasound. Through positive behavioural reinforcement, whales' reproductive organs can be monitored via ultrasound and reproductive hormones can be measured by obtaining voluntary samples of blood, urine and breath. These biological measurements can be paired with behavioural ethograms to answer questions about the mating and breeding of belugas. 
Aquaria maintaining male belugas have contributed to studies that investigate and monitor seasonal fluctuations in testes size and reproductive hormones under controlled conditions to contribute to knowledge on male beluga reproduction (Richard et al. 2016; Richard et al. 2017). Data can be collected on belugas throughout the entire year, yielding insights into baseline rhythms and seasonal fluctuations of the reproductive system, which is challenging to understand in wild belugas.

Studies such as these build up our overall knowledge of beluga breeding, birthing and calf-rearing and the critical early life stages. Understanding beluga mating strategies will be useful to wildlife managers in making management decisions to support breeding among wild populations of belugas, especially smaller populations such as Cook Inlet. Sex- or age-biased removals can disrupt social structures and mating systems, especially in small populations, reducing fecundity and causing population declines (e.g., Ginsburg \& Milner-Gulland 1994; Stubberud et al. 2019). Given their social structure and exposure to anthropogenic influences, belugas may be particularly vulnerable to these types of disruptions (Wade et al. 2012). Through the study of aquarium belugas, Richard et al. (2021 [this special cluster]) find evidence that beluga mating strategies may not be strictly polygynous, providing a foundation for future investigations in wild belugas that may be useful for explaining the lack of recovery in small populations and ensuring the sustainability of subsistence-hunted belugas, in which large males are often targeted.

\section{Tracking, monitoring and testing telemetry and camera prototypes}

Given environmental changes and anthropogenic challenges, tracking and monitoring belugas in the wild is becoming critical for collecting important information on whales, such as movements in relation to changing ice patterns and anthropogenic stressors (Citta et al. 2013; Hauser et al. 2014; Hauser et al. 2015; Vacquie-Garcia et al. 2018). The technology in tracking and sensing devices deployed on marine mammals_for measuring environmental parameters like temperature, salinity and location as well as monitoring dive frequency, depth and movements-is constantly being improved but can be expensive (Hauser et al. 2015; Laplanche et al. 2015; Nowacek et al. 2016; Goldbogen et al. 2017).

In collaboration with Mystic Aquarium's scientist-in-residence, Greg Marshall, inventor of Critter Cam ${ }^{\circledR}$, Mystic Aquarium tested a camera on one resident beluga to gain as much information as possible before the device was deployed on a wild beluga (Fig. 3). One whale was trained to station and receive the camera, which was

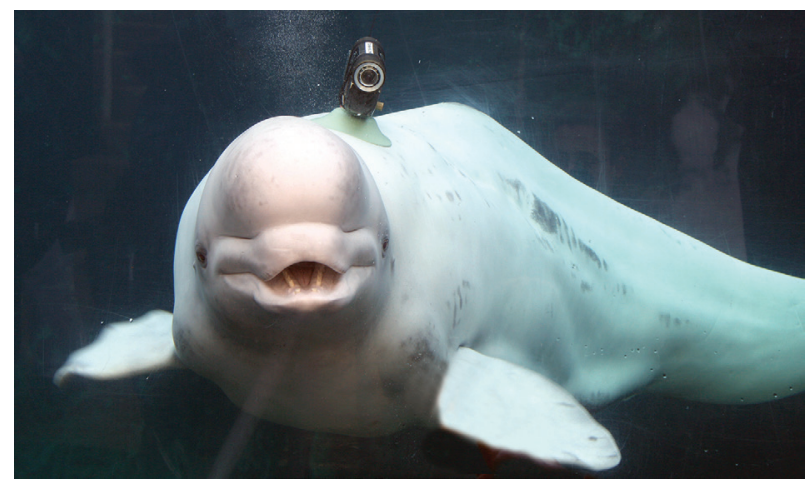

Fig. 3 A Crittercam is tested on a beluga residing at Mystic Aquarium before deployment on wild whales.

adhered via suction cups. Tests were run to determine the optimal placement on the body. Two different-sized prototypes were tested. Adherence was tested utilizing different sizes and configurations of suction cups. Observations were made while the whale was swimming normally and when it voluntarily engaged in rigorous activity, such as breaching and swimming fast, to test the device's limitations. Such tests and proofs-of-concept allow scientists to perfect devices before deploying them on wild whales, improving the chances of successfully monitoring wild whales. These technologies, paired with knowledge of environmental changes and anthropogenic human activities (e.g., pile-driving, mineral extraction, sonar, oil spills), can provide patterns of movement and diving, as well as acoustical signals before and after these activities. Mitigation measures can be put into place (Wade et al. 2006; Kennedy et al. 2014) to limit the negative effects on belugas.

\section{Hearing and physiological response to anthropogenic sound}

The critical habitat of the Cook Inlet beluga is concentrated near Anchorage, the largest urban area in Alaska. The whales in this area are exposed to a wide variety of noise stressors, including mining, dredging, military operations, oil and gas development, transportation and shoreline development (Castellote et al. 2018). Noise can affect foraging, hearing, navigation and reproduction in cetaceans (Halliday et al. 2017; Putland et al. 2017). It is important to understand how these noise stressors effect hearing and communication, behaviour and health. In controlled studies of beluga and bottlenose dolphin, exposure to impulsive and tonal sounds activated a physiological response, with changes in immune function (Romano et al. 2004) that could have negative consequences on health. 
The aquarium setting allows for investigation of the impact of anthropogenic sound on beluga hearing and physiology. In collaboration with Mystic Aquarium scientists-in-residence, Aran Mooney, of the Woods Hole Oceanographic Institution, and Manuel Castellote, of the University of Washington and Alaska Fisheries Science Center, NOAA, preliminary proof-of-concept hearing studies were carried out on one beluga at Mystic Aquarium under controlled conditions. The whale was trained to station and accept suction cup electrodes to measure non-invasive AEPs. An audiogram was obtained to compare with wild belugas (Castellote et al. 2014; Mooney et al. 2018). Moreover, a controlled noise exposure experiment was carried out in which the whale was exposed to the low levels of anthropogenic noise (ships and pile-driving) that regularly occur in the Cook Inlet beluga critical habitat. Although the level is below the regulatory acoustic exposure threshold, the aquarium study suggests that the noise can mask beluga hearing sensitivity and has the potential to compromise vital functions, such as foraging, in wild belugas. This study contributes to CIBRP Action \#30- “Describe the acoustic characteristics of different anthropogenic noise sources in Cook Inlet and rate the potential acoustic impacts from each type of noise source on Cook Inlet belugas". AEPs carried out on whales in Bristol Bay showed similar audiograms to that of the beluga at Mystic Aquarium (Mooney et al. 2018; Castellote, pers. comm.).

Utilizing trained whales in aquaria will help us understand the effects of noise to which belugas are subjected in the wild and aid in management and conservation by providing data to help with mitigation measures, for example, informing the regulation of industrial underwater noise emissions. Controlled studies with whales in aquaria can help answer questions about different sounds of interest, quantify frequencies that are masked (if they are masked), and determine the difference in $\mathrm{dB}$ between baseline thresholds and masked thresholds. They will also allow us to quantify the directional hearing abilities of belugas in order to address how masking release could be achieved by a beluga turning its head away from the noise. Furthermore, using non-invasive biological sampling, e.g., collecting breath and saliva, will permit us to measure the physiological responses to sound more efficiently than using blood samples (Romano et al. 2004).

\section{Studies to inform photogrammetry}

Photogrammetry, a technique that uses quantitative measurements from photographs, has been utilized to collect cetacean measurements, such as length, growth and body condition, to infer health information on individual cetaceans or to determine group abundance and structure (Jaquet 2006; Webster et al. 2010; Cheney et al. 2017). More recently, surveys with UAVs are replacing more expensive aerial surveys to monitor cetacean populations at risk (Durban et al. 2018). Photogrammetry with UAVs has recently been used for monitoring beluga populations such as those in Cook Inlet and the St. Lawrence Estuary. Getting the most out of such surveys requires reliable reference measurements of healthy male and female whales in good body condition, at different ages. Ascertaining reproductive status and identifying pregnant whales in a population are also key in determining the health, reproductive success and viability of beluga populations.

Mystic Aquarium and other facilities that care for belugas are participating in a study to provide longitudinal photogrammetry and morphometric data from known individual belugas, to inform photogrammetry studies of wild beluga populations, such as the St. Lawrence Estuary (Vergara et al. 2019; Fig. 4) and Cook Inlet whales. This study contributes to CIBRP Actions \#5 and \# 14: “Determine annual mortality and reproductive rates of Cook Inlet belugas" and "Monitor body condition of living and deceased Cook Inlet belugas to assess the presence/absence of nutritional distress or nutritional-related mortalities and determine the percentage of necropsied Cook Inlet beluga with mortalities attributed to nutritional distress". The data will aid in developing a minimally invasive method to assess body condition in beluga whales in the wild using photographs taken with UAVs. Wildlife biologists will be able to better interpret and equate photogrammetry measurements with reference values from known healthy whales at different life stages.

\section{Animal care and husbandry}

In addition to research, aquarium professionals have years of experience and expertise in animal care and husbandry, including such aspects as animal handling, animal behaviour, biological sampling, preventive and rehabilitative veterinary care, formulas for raising calves, diets, nutrition and more. Aquarium animal husbandry professionals and veterinarians have played key roles in the rescue, rehabilitation, relocation and release of stranded marine mammals, resulting in successful tracking and monitoring for several months and, in some cases, evidence that the whales rejoined larger groups of similar species (Nawojchik \& St. Aubin 2003; Tyson-Moore et al. 2020; Ready et al. 2021). This expertise in animal handling, veterinary medicine and biological sampling are key assets during capture-release studies of belugas. 

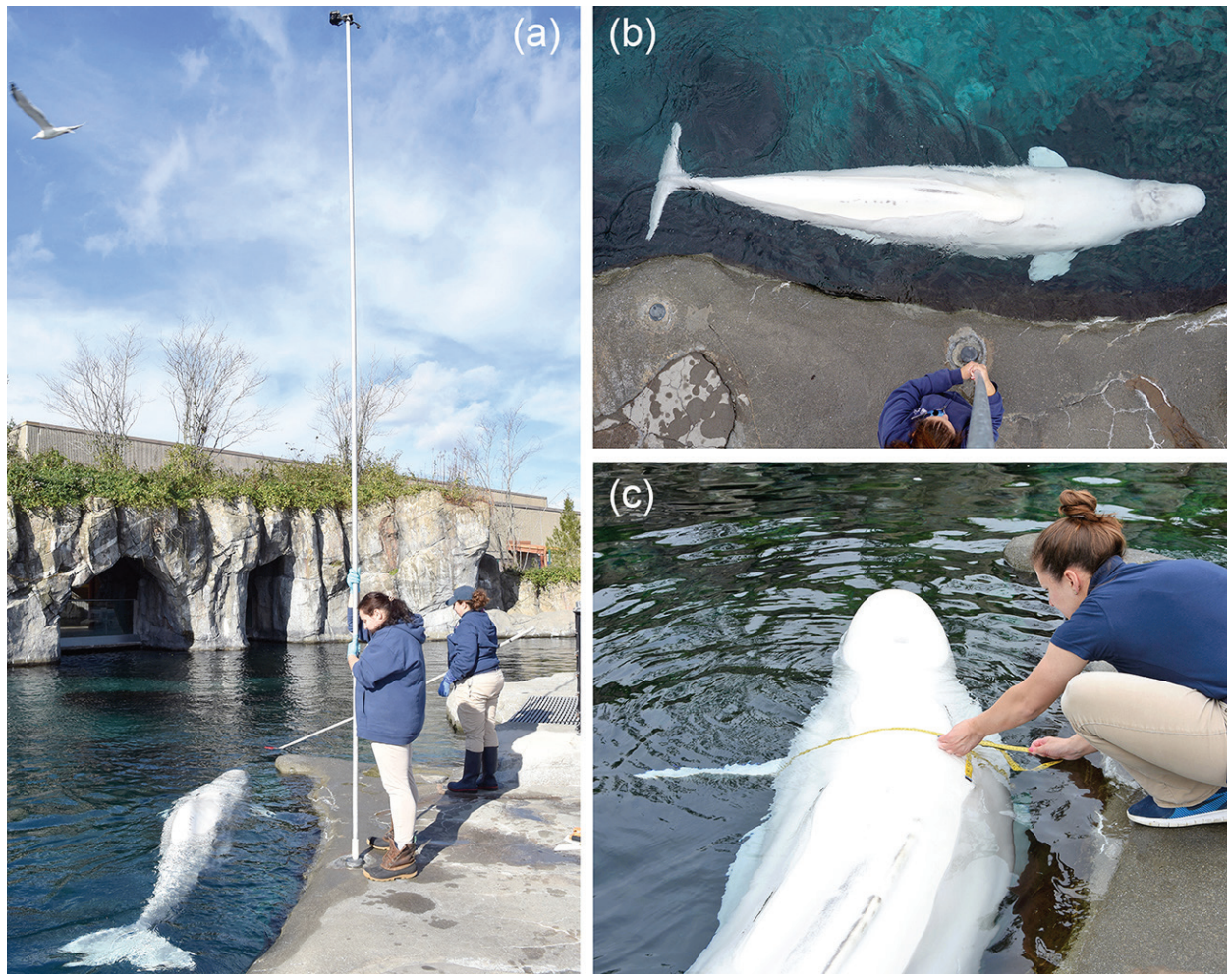

Fig. 4 UAV photographs are simulated with photographs taken by a camera mounted on a pole at height. (a) Belugas are trained to swim underneath the camera. (b) Example of a resulting photograph. (c) Morphometrics are recorded to pair with photographs.

One of the most prominent success stories is the recent case study of Tyonek, a stranded Cook Inlet beluga calf that was rescued and brought to the Alaska SeaLife Center for rehabilitation (Goertz et al. 2021 [this special cluster]). Led by the Alaska SeaLife Center, aquaria in the US with beluga expertise were involved in the care and rehabilitation of this calf. Aquaria staff provided hands-on care and handling, a nutritious formula to feed the calf, parameters with which to estimate his age and weight data against which to measure his progress. Aquaria also allocated funds for the care of the calf. The Cook Inlet calf recovered having contributed to our knowledge of wild beluga neonates-including pathogens, hearing and various physiological and metabolic parameters-and how to save stranded beluga calves. The case is promising for future rehabilitation efforts with the potential for release back into the wild.

When three belugas showed up in Narragansett Bay, RI, and headed to Long Island Sound in May 2015, Mystic Aquarium's animal rescue and research teams tracked them, monitored their behaviour and promoted their safety through education efforts. Educational messaging was distributed to harbour masters and marinas throughout Long Island Sound, informing boaters to maintain a safe distance from the whales, an instruction that may have been particularly decisive during the crowded holiday weekend. The team sent photographs (Fig. 5) to Robert Michaud, of the Group for Research and Education on Marine Mammals, a non-profit organization based in Canada, to determine if any of the whales were in the St. Lawrence Estuary image database. They also worked with NOAA scientists to obtain remote skin biopsies. One of the whales was identified as being from the endangered St. Lawrence Estuary stock. The whales were spotted off the coast of Nova Scotia several weeks later. Out-of-habitat belugas may become more frequent because of climate change, requiring similar local mobilization by aquaria as well as rapid international cooperation.

\section{Education and outreach}

Aquaria are uniquely positioned for education and outreach. Studies have documented increases in zoo and aquaria visitors' knowledge about, and perception of connection to, animals, as well as pro-conservation behaviours (Skibins et al. 2013; Pearson et al. 2014; Jensen et al. 2016; Mellish et al. 2019). In 2019 alone, 

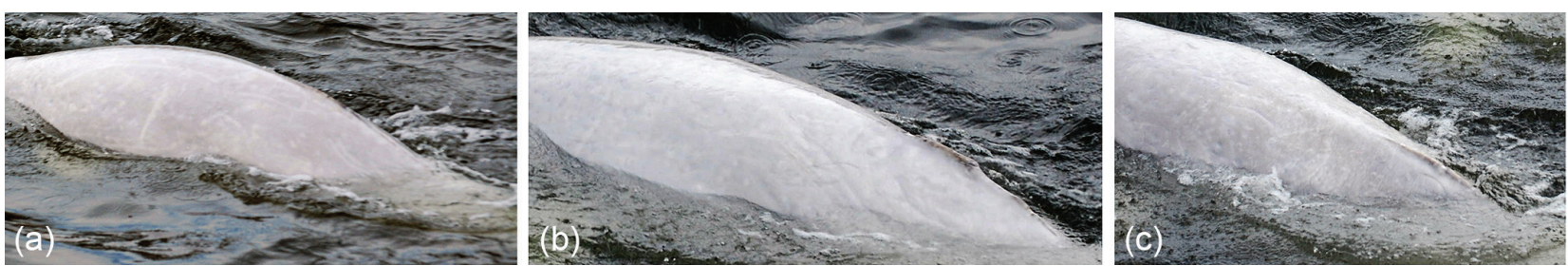

Fig. 5 The three out-of-habitat belugas were photographed for identifying characteristics of their dorsal ridges. One of the whales was confirmed as being from the St. Lawrence Estuary, Canada.

Mystic Aquarium enabled over 4000 aquarium patrons, school students, campers and Scouts direct engagement with beluga-focused educational programming. Additionally, some 800000 aquarium visitors annually are given the opportunity to be engaged and educated (Miller et al. 2013) on belugas through exhibit interpretation; most of these people would otherwise never get to see live belugas. Mystic Aquarium's beluga-focused educational programmes provide an opportunity to educate visitors about the climate change-related and anthropogenic threats affecting marine mammals, conservation efforts and federal US regulations (such as the Marine Mammal Protection and Endangered Species Acts) that protect marine mammals and ecosystems, while simultaneously engaging visitors in memorable experiences. Each programme concludes by reinforcing the importance of maintaining healthy oceans and marine mammal populations and our collective responsibility for this.

Special interactive programmes bring people closer to belugas, allowing them to interact with the whales, learn details about their behaviours and training, and engage in dialogue with the whale trainers. These experiences can be transformative, enhancing participants' appreciation for whales and deepening their engagement with the issues facing these animals in the wild, as has been shown for other zoo and aquarium species (Miller et al. 2013; Skibins et al. 2013).

Along with other aquaria, Mystic Aquarium engages the public beyond its campus through virtual or on-site participation in the Belugas Count event, an all-day citizen science celebration of Cook Inlet belugas for the public in Anchorage, AK. The event is sponsored by NOAA and its partners to raise awareness of the endangered Cook Inlet beluga whale with the intent of fostering awareness and stewardship. Mystic Aquarium has provided viewing of research whale training sessions online and presentations illustrating how aquarium whales contribute to knowledge that benefits their wild counterparts.

\section{A science-based educational and cultural exchange programme for Alaska Native and Native American youth}

Special educational programmes that highlight belugas evolved from ongoing research partnerships with the community of Point Lay, AK, and the NSB-DWM. Mystic Aquarium scientists work with Robert Suydam (NSBDWM) and the community of Point Lay to collect and analyse life history and health information from Chukchi Sea belugas to establish baseline information and provide comparative data for Cook Inlet and other beluga stocks. Based on this research, an educational and cultural exchange programme was established for Alaska Native and Native American youth. The major goals of the programme are to: (1) stimulate interest and excitement about science via hands-on learning; (2) introduce students to educational opportunities and careers in science; (3) enable the cohort to learn and share their traditions and culture; and 4) foster the realization that each participant can be a resource to her or his community for the management and sustainability of belugas and other marine resources.

The programme begins in Point Lay, when Mystic Aquarium and NSB-DWM scientists conduct fieldwork on wild belugas during the summer. The youth assist with live capture, tagging, sampling and release studies of belugas and the collection of data and samples from subsistence-harvested belugas. Subsequently, the youth travel to Mystic to participate in hands-on beluga research, analyse samples collected and learn what the samples reveal. Students also participate in learning activities focused on beluga biology, the local marine environment, other aspects of science and husbandry and various career opportunities, and they visit local and regional historical and cultural sites (Fig. 6). Culture is exchanged and shared among the cohort, with time spent at the Mashantucket Pequot Museum and Research Center and the Mashantucket Pequot Reservation. During their visit to the reservation, the students have an 

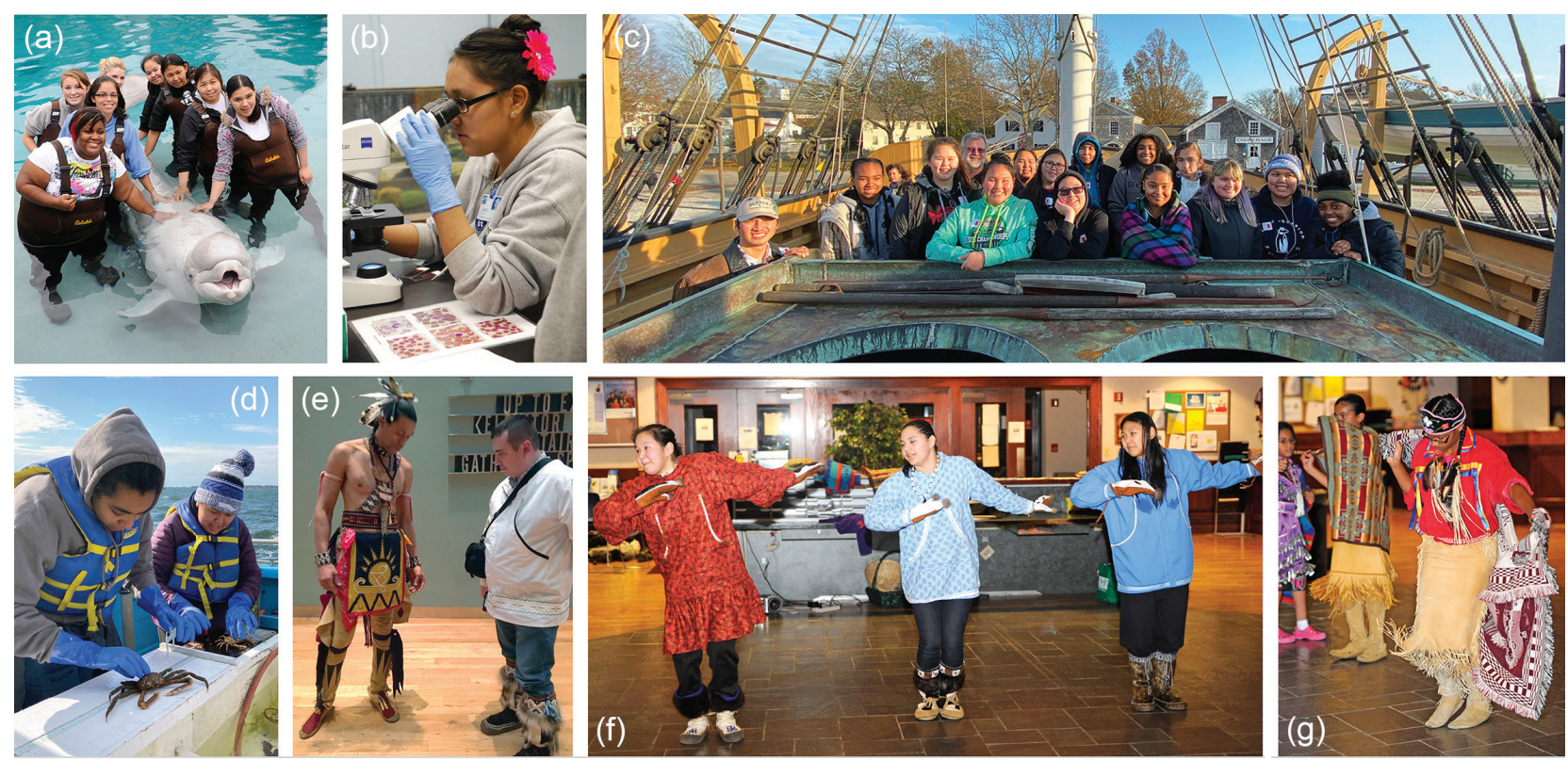

Fig. 6 High school youth from villages on the North Slope of Alaska (Point Lay, Wainwright, Utqiagvik, Point Hope) and local tribal youth (Mashantucket Pequot Tribal Nation (Mashantucket, CT) and the Narrangansett Tribe (Narrangansett, RI) participate in a science-based educational and cultural exchange programme hosted by the Mystic Aquarium. (a) Students participate in beluga interactive programmes to learn about beluga biology and research and conservation efforts. (b) Students participate in hands-on science, e.g., examining and counting beluga blood cells under the microscope. (c) Students visit local historic sites such as the Charles W. Morgan, the last ship of an American whaling fleet maintained at the Mystic Seaport. (d) Students collect biological and environmental data as part of a research cruise on Long Island Sound (Project Oceanology, Groton, CT). (e-g) Indigenous traditions and culture are shared, including Native dress and dance.

opportunity to interact with tribal members and participate in native crafts, dance and sports. Following the programme, the students are encouraged to return to Mystic Aquarium or to work with the NSB-DWM as research interns, participate in other science programmes and science camps and conferences, pursue higher education, and share their learning experience with other youth and their communities. The cohort from November 2019 had the opportunity to attend the Alaska Beluga Whale Committee meeting in Anchorage and present their experiences there. The desired outcome of the programme is engagement and education that leads towards local involvement in the management and sustainability of belugas.

Both internal and external evaluations indicate that the youth are positively impacted by their experiences. For example, students were given a pre-survey to determine their state of knowledge of key concepts covered during the programme as well as attitudes towards science. The same survey was given to the students after the programme. Most students showed an increase in knowledge and rated attitudes toward science higher than in the pre-survey. Moreover, the external independent evaluator and consultant report (Harkins 2012) indicated that through the duration of the programme: students increased their understanding of the week's science content, such as beluga husbandry, marine mammal adaptations, DNA, blood sampling and other tests, necropsy and marine environment exploration; students used more science terminology; students learned more substantially from hands-on explorations than they did from presentation-style activities; students were able to identify similarities and differences between Iñupiat and Mashantucket Pequot cultures; and many of the cross-cultural experiences during the programme were spontaneous among the cohort, such as sharing and demonstration of games and dances.

\section{Mystic Aquarium Research Experiences for Undergraduates Site}

Mystic Aquarium is the only aquarium that currently has a National Science Foundation supported Research Experiences for Undergraduates site, which supports the training of 10 undergraduate students annually during the summer months. Research is conducted at UConn's 
Avery Point campus, in Groton, which currently hosts Mystic Aquarium's laboratories and collaborative partner UConn's Department of Marine Sciences. Over the next three years, it is anticipated that 30 students, primarily from underrepresented groups and schools with limited research opportunities, will be trained in the programme. Students will learn how research is conducted, will present their findings for both scientific and public audiences and may present the results of their work at scientific conferences.

The Research Experiences for Undergraduates programme focuses on how global change, such as climate change, affects marine organisms and their ecosystems. Mystic Aquarium and UConn scientists, who specialize in aquatic animal physiology, behaviour and ecological processes, mentor the students. Field trips to Mystic Aquarium are a major component of this immersive experience, including educational tours, animal and ecosystem exhibit observations, job shadowing, the responsible conduct demanded by ethical research, and science communication. To date, four students have had research experiences focused on belugas and three of them participated in field research in Alaska. The Mystic Aquarium Research Experiences for Undergraduates programme is evaluated by each cohort through Undergraduate Research Students Self-Assessment, an online survey instrument for use in evaluating student outcomes of undergraduate experiences in the sciences that is recommended by the National Science Foundation. The following are examples of featured conceptual elements and Mystic Aquarium's aggregate scores for the first three years of the programme (2017-19): "personal gains related to research" (range 4.5 - 4.9 out of 5.0), "gains in skills" (range 3.6 - 4.7 out of 5.0), "attitudes and behaviours as a researcher" (range 4.1 - 4.9 out of 5.0), "thinking and working like a scientist" (range 4.2 - 4.9 out of 5.0). The high scores indicate that the programme is having a positive effect on undergraduates (Westen \& Larsen 2015). Students are currently being tracked over time. The majority of students who have graduated from university have gone on to graduate school or have secured jobs in the fields of science, technology, engineering or math.

\section{Conclusion}

There has never been a time in history when the conservation and understanding of belugas and other cetaceans has been more important than it is today. Climate change, pollution, offshore oil and gas exploration, shipping and other anthropogenic factors threaten beluga populations and, especially, the recovery of endangered stocks. Aquaria can provide unique opportunities that inform and support the conservation of wild belugas through research, expertise in care and husbandry and engaging and educating people of all ages and backgrounds to promote a sense of responsibility that will inspire conservation-based actions for belugas, other marine species and our oceans. In this constantly changing environment, the future of belugas is in all of our hands. It is only through working together and combining our diverse expertise and resources that we can gain ground with meaningful research, recovery of endangered populations, and management of belugas to ensure their sustainability for generations to come.

\section{Acknowledgements}

We recognize, acknowledge and are grateful to our colleagues and all aquaria in the US that maintain belugas under their professional care (Shedd Aquarium, Chicago, IL; Sea World, Orlando, FL, San Antonio, TX, and San Diego, CA; Georgia Aquarium, Atlanta; Mystic Aquarium, Mystic, CT), as well as others internationally who have made and are making contributions to beluga research, education and conservation. The beluga research programme at Mystic Aquarium is only possible through the dedicated animal care, veterinary and husbandry teams that provide optimal care for the belugas on a daily basis and training for the research projects. The education, interpretation, exhibits and public relations teams help to translate the beluga research and need for conservation. We thank Cheryl Miller, Mystic Aquarium's public relations team and Leslie Pierce (DWM-NSB) for the photographs used in the figures. Heather Harkins is acknowledged for the evaluation of our educational and cultural exchange programme. We thank Mystic Aquarium's Chair, Dr George Milne, the Board of Trustees and Aquarium leadership, the Research Advisory Council, scientists-in-residence and Institutional Animal Care and Use Committees for their commitment and support of the research programme. We are grateful and appreciate all of our collaborators and colleagues who work with us, have contributed and are supportive of Mystic Aquarium's beluga research and education efforts. A special thanks to the Mashantucket Pequot Tribal Nation and the community of Point Lay, AK. This constitutes scientific contribution no. 318 from the Sea Research Foundation, Inc. A version of this paper was presented at the Second International Workshop on Beluga Whale Research and Conservation, 12-14 March 2019, held at Mystic Aquarium.

\section{Disclosure statement}

The authors are employed by Mystic Aquarium. 


\section{Funding}

Financial support for research and education efforts has been provided by the Office of Naval Research, SeaWorld and Bush Gardens Conservation Fund, National Fish and Wildlife Foundation, The Bulrush Foundation, The Oak Foundation, the US National Science Foundation (grant nos. 1931117 and 1658663), NOAA, the Mayor of the North Slope Borough, The Tribal Council of the Mashantucket Pequot Tribal Nation, the Sea Research Foundation, Inc. (d/b/a Mystic Aquarium) and the generous support of its donors.

\section{References}

Acevedo-Whitehouse K., Rocha-Gosselin A. \& Gendron D. 2010. A novel non-invasive tool for disease surveillance of free-ranging whales and its relevance to conservation programs. Animal Conservation 13, 217-225, doi: 10.1111/j.1469-1795.2009.00326.x.

Aguilar Soto N., Johnson M., Madsen P.T., Tyack P.L., Bocconcell A. \& Borsani J.F. 2006. Does intense ship noise disrupt foraging in deep-diving Cuvier's beaked whales (Ziphius Cavirostris)? Marine Mammal Science 22, 690-699, doi: $10.1111 / \mathrm{j} .1748-7692.2006 .00044 . x$.

Apprill A., Miller C.A., Moore M.J., Durban J.W., Fearnbach H. \& Barrett-Lennard L.G. 2017. Extensive core microbiome in drone-captured whale blow supports a framework for health monitoring. mSystems 2, e00119-17, doi: 10.1128/mSystems.00119-17.

Bossart G.D., Romano T.A., Peden-Adams M.M., Rice C.D., Fair P.A., Goldstein J.D., Kilpatrick D., Cammen K. \& Reif J.S. 2008. The hematological, biochemical, and immunological findings in Atlantic bottlenose dolphins (Tursiops truncatus) with orogenital papillomas. Aquatic Mammals 34 , 166-177, doi: 10.1578/AM.34.2.2008.166.

Bossart G., Romano T.A., Peden-Adams M.M., Schaefer A.M., Rice C.D., Fair P.A. \& Rice J.S. 2019. Comparative innate and adaptive immune responses in Atlantic bottlenose dolphins (Tursiops truncatus) with viral, bacterial and fungal infections. Frontiers in Immunology 10, article no. 1125, doi: 10.3389/fimmu.2019.01125.

Brando S. 2010. Advances in husbandry training in marine mammal care programs. International Journal of Comparative Psychology 23, 777-791.

Burek K.A., Gulland M.D. \& O'Hara T.M. 2008. Effects of climate change on Arctic marine mammal health. Ecological Applications 18, S126-S134, doi: 10.1890/06-0553.1.

Castellote M., Mooney T.A., Quakenbush L., Hobbs R., Goertz C.E. \& Gaglione E. 2014. Baseline hearing abilities and variability in wild beluga whales (Delphinapterus leucas). Journal of Experimental Biology 217, 1682-1691, doi: 10.1242/jeb.093252.

Castellote M., Thayre B., Mahoney M., Mondragon J., Lammers M.O. \& Small R.J. 2018. Anthropogenic noise and the endangered Cook Inlet beluga whale, Delphinapterus leucas, acoustic considerations for management. Marine Fisheries Review 80, 63-88, doi: 10.7755/MFR.80.3.3.

Cheny B., Well R.S., Barton T.R. \& Thompson P.M. 2017. Laser photogrammetry reveals variation in growth and early survival in free-ranging bottlenose dolphins. Animal Conservation 21, 2532-261, doi: 10.1111/acv.12384.

Citta J.J., Suydam R.S., Quakenbush L.T., Frost K.J. \& O'Corry-Crowe G.M. 2013. Dive behavior of eastern Chukchi beluga whales (Delphinapterus leucas) 1998-2008. Arctic 66, 389-406.

Corkeron P.J. 1995. Humpback whales (Megaptera novaeangliae) in Hervey Bay, Queensland: behavior and responses to whale-watching vessels. Canadian Journal of Zoology 73, 1290-1299, doi: 10.1139/z95-153.

De Guise S.J, Erickson K., Blanchard M., DiMolfetto L., Lepper H., Wang J., Stott J.L. \& Ferrick D.A. 2002. Monoclonal antibodies to lymphocyte surface antigens for cetacean homologues to CD2, CD19 and CD21. Veterinary Immunology and Immunopathology 84, 209-221, doi: 10.1016/S0165-2427(01)00409-3.

De Guise S.J., Ross P.S., Osterhaus A.D., Martineau D., Béland P. \& Fournier M. 1997. Immune functions in beluga whales (Delphinapterus leucas): evaluation of natural killer cell activity. Veterinary Immunology and Immunopathology 58, 345-354, doi: 10.1016/S0165-2427(97)00035-4.

Durban J.W., Fearnback H., Barrett-Lennard L.G., Perryman W.L. \& Leroi D.J. 2018. Photogrammetry of killer whales using a small hexacopter launched at sea. Journal of Unmanned Vehicle Systems 3, 131-135, doi: 10.1139/ juvs-2015-0020.

Fair P.A. \& Becker P.R. 2000. Review of stress in marine mammals. Journal of Aquatic Ecosystem Stress and Recovery 7, 335-354, doi: 10.1023/A:1009968113079.

Fair P.A., Romano T.A., Schaefer A.M., Reif J.S., Bossart G.D., Houde M., Muir D., Adams J., Rice C., Hulsey T.C. \& Peden-Adams M. 2013. Associations between perfluoroalkyl compounds and immune and clinical chemistry parameters in highly exposed bottlenose dolphins (Tursiops Truncatus). Environmental Toxicology Chemistry 32, 736-746, doi: $10.1002 /$ etc. 2122 .

Fair P., Schaefer A.D., Houser D.S., Bossart G.D., Romano T.A., Champagne C.D., Stott J.L., Rice C.D., White N. \& Reif J.S. 2017. The environment as a driver of immune and endocrine responses in dolphins (Tursiops truncatus). PLoS One 12, e0176202, doi: 10.1371/journal.pone.0176202.

Fair P.A., Schaefer A.M., Reif J.S., Bossart G.D. \& Romano T.A. 2014. Stress response of wild bottlenose dolphins (Tursiops truncatus) during capture-release health assessment studies. General Comparative Endocrinology 9, 203212, doi: 10.1016/j.ygcen.2014.07.002.

Flower J.E., Allender M.C., Giovanelli R.P., Summers S.D., Spoon T.R., St. Leger J.A., Goertz C.E., Dunn J.E., Romano T.A., Hobbs R.C. \& Tuttle A.D. 2015. Circulating concentrations of thyroid hormone in beluga whales (Delphinapterus leucas): influence of age, sex and season. Journal of Zoo and Wildlife Medicine 46, 456-467, doi: 10.1638/2014-0127.1.

Ford J.D., Smit B. \& Wandel J. 2006. Vulnerability to climate change in the Arctic: a case study from Arctic Bay, Canada. 
Global Environmental Change 16, 145-160, doi: 10.1016/j. gloenvcha.2005.11.007.

Ginsberg J.R. \& Milner-Gulland E.J. 1994. Sex-biased harvesting and population dynamics in ungulates: implications for conservation and sustainable use. Conservation Biology 8 , 157-166, doi: 10.1046/j.1523-1739.1994.08010157.x.

Goertz C.E.C., Woodie K., Long B., Hartman L., Gaglione E., Christen D., Clauss T., Flower J., Tuttle A., Richard C., Romano T., Schmitt T., Otjen E., Osborn S., Aibel S., Binder T., Van Bonn W., Castellote M., Mooney T.A., DennisonGibby S., Burek-Huntington K. \& Rowles T.K. 2021. Stranded beluga (Delphinapterus leucas) calf response and care: reports of two cases with different outcomes. Polar Research 40, article no. 5514, doi: 10.33265/polar.v39.5514.

Goldbogen J.A., Cade D.E., Boersma A.T., Calambokidis J., Kahane-Rapport S.R., Segre P.S., Stimpert A.K. \& Friedlander A.S. 2017. Using digital tags with integrated video and inertial sensors to study the moving morphology and associated function in large aquatic vertebrates. Anatomical Record 300, 1935-1941, doi: 10.1002/ar.23650.

Halliday W.D., Insley S.J., Hilliard R.C., de Jong T. \& Pine M.K. 2017. Potential impacts of shipping noise on marine mammals in the western Canadian Arctic. Marine Pollution Bulletin 123, 73-82, doi: 10.1016/j.marpolbul.2017.09.027.

Harkins H. 2012. Point Lay Educational and Cultural Exchange Program October 2011 evaluation report. Unpublished.

Hauser D.D.W. 2016. Beluga whale distribution, migration, and behavior in a changing Pacific Arctic. PhD thesis, University of Washington.

Hauser D.D.W., Laidre K.L., Parker-Stetter S.L., Horne J.K., Suydam R.S. \& Richard P.R. 2015. Regional diving behavior of Pacific Arctic beluga whales Delphinapterus leucas and possible associations with prey. Marine Ecology Progress Series 541, 245-264, doi: 10.3354/meps 1530.

Hauser D.D.W., Laidre K.L., Suydam R.S. \& Richard P.R. 2014. Population-specific home ranges and migration timing of Pacific Arctic beluga whales (Delphinapterus leucas). Polar Biology 37, 1171-1 183, doi: 10.1007/s00300-014-1510-1.

Hauser D.D.W., Laidre K.L., Stern H.L., Suydam R.S. \& Richard P.R. 2018. Indirect effects of sea ice loss on summer-fall habitat and behaviour for sympatric populations of an Arctic marine predator. Biodiversity Research 24, 791799, doi: $10.1111 /$ ddi.12722.

Hunt K., Rolland R. \& Kraus S. 2013. Detection of steroid and thyroid hormones via immunoassays of North Atlantic right whale (Eubalaena glacialis) respiratory vapor. Marine Mammal Science 30, 796-809, doi: 10.1111/mms.12073.

Isojunno S., Sadykova D., DeRuiter S., Cure C., Visser F., Thomas L., Miller P.J.O. \& Harris C.M. 2017. Individual, ecological and anthropogenic influences on activity budgets of long-finned pilot whales. Ecosphere 8, e02044, doi: $10.1002 /$ ecs2.2044.

Jaquet N. 2006. A simple photogrammetric technique to measure sperm whales at sea. Marine Mammal Science 22, 862-879, doi: 0.1111/j.1748-7692.2006.00060.x.

Jensen E., Moss A. \& Gusset M. 2017. Quantifying long-term impact of zoo and aquarium visits on biodiversity-related learning outcomes. Zoo Biology 36, 294-297, doi: 10.1002/ zoo. 21372 .
Kennedy A.S., Zerbini A.N., Rone B.K. \& Clapham P.J. 2014. Individual variation in movements of satellite-tracked humpback whales Megaptera novaeangliae in the eastern Aleutian Island and Bering Sea. Endangered Species Research 23, 187-195, doi: 10.3354/esr00570.

Keogh M.J., Spoon T.R., Ridgway S.H., Jensen E., Van Bonn W. \& Romano T.A. 2011. Simultaneous measurement of phagocytosis and respiratory burst of leukocytes in whole blood from bottlenose dolphins (Tursiops truncatus) utilizing flow cytometry. Veterinary Immunology Immunopathology 144, 468-475, doi: 10.1016/j.vetimm.2011.08.017.

Kovacs K.M., Lydersen C., Overland J.E. \& Moore S.E. 2011. Impacts of changing sea-ice conditions on Arctic marine mammals. Marine Biodiversity 41, 181-194, doi 10.1007/ s12526-010-0061-0.

Kuczaj S. \& Xitco M. 2002. It takes more than fish: the psychology of marine mammal training. Journal of Comparative Psychology 15, 186-200.

Laplanche C., Marques T.A. \& Thomas L. 2015. Tracking marine mammals in 3D using electronic tag data. Methods in Ecology and Evolution 6, 987-996, doi: 10.1111/2041$210 X .12373$.

Lise S., Petter K., Fhalman A., Frans-Peter L., Tyack P. \& Miller P. 2012. Changes in dive behavior during naval sonar exposure in killer whales, long-finned pilot whales, and sperm whales. Frontiers in Physiology 3, article no. 400, doi: 10.3389/fphys.2012.00400

Lusseau D. 2003. Male and female bottlenose dolphins Tursiops spp. have different strategies to avoid interactions with tour boats in doubtful sound, New Zealand. Marine Ecology Progress Series 257, 267-274, doi: 10.3354/ meps257267.

Mancia A., Lundqvist M., Romano T., Peden-Adams M., Fair P., Kindy M., Ellis B., Gattoni-Celli S., McKillen D., Trent H., Chen Y., Almeida J., Gross P., Chapman R. \& Warr G. 2007. A dolphin peripheral blood leukocyte cDNA microarray for studies of immune function and stress reactions. Developmental Comparative Immunology 31, 520-529, 10.1016/j.dci.2006.07.011

Meegan J., Dunn J.L., Venn-Watson S.K., Smith C.R., Sidor I., Jensen E.D., Van Bonn W.G., Pugh R., Ficht T., Adams L.G., Nielsen K. \& Romano T.A. 2012. Serologic response in bottlenose dolphins (Tursiops truncatus) infected with Brucella sp. using a dolphin-specific indirect ELISA. Diseases of Aquatic Organisms 102, 73-85, doi: 10.3354/dao02528.

Meegan J., Field C., Sidor I., Romano T., Casinghino S., Smith C.R., Kashinksy L., Fair P.A., Bossart G., Wells R. \& Dunn J.L. 2010. Development, validation, and utilization of a competitive enzyme-linked immunosorbent assay for detection of antibodies against Brucella species in marine mammals. Journal of Veterinary Diagnostic Investigation 22, 856-862, doi: 10.1177/104063871002200603.

Mellish S., Pearson E.L., McLeod E.M., Tuckey M.R. \& Ryan J.C. 2019. What goes up must come down: an evaluation of a zoo conservation-education program for balloon litter on visitor understanding, attitudes, and behaviour. Journal of Sustainable Tourism 27, 1393-1415, doi: 10.1002/zoo.21372.

Miller L.J., Zeigler-Hill V., Mellen J., Koeppel J., Greer T. \& Kuczaj S. 2013. Dolphin shows and interaction programs: 
benefits for conservation education? Zoo Biology 32, 45-53, doi: 10.1002/zoo.21016.

Mooney T.A., Castellote M., Quakenbush L., Hobbs R., Gaglione E. \& Goertz C. 2018. Variation in hearing within a wild population of beluga whales (Delphinapterus leucas). Journal of Experimental Biology 221, article no. jeb171959, doi: $10.1242 /$ jeb.171959.

Moore S.E. \& Huntington H.P. 2008. Arctic marine mammals and climate change: impacts and resilience. Ecological Applications 18, S157-S165, doi: 10.1890/06-0571.1.

NMFS (National Marine Fisheries Service) 2016. Recovery plan for the Cook Inlet beluga whale (Delphinapterus leucas). Juneau, AK: National Marine Fisheries Service, Alaska Region, Protected Resources Division.

Nawojchik R. \& St. Aubin D.J. 2003. Movements and dive behavior of two stranded, rehabilitated long-finned pilot whales (Globicephala melas) in the Northwest Atlantic. Marine Mammal Science 19, 232-239, doi: 10.1111/j.17487692.2003.tb01105.x.

Nowacek D., Christiansen F., Bejder L., Goldboye J.A. \& Friedlander A.S. 2016. Studying cetacean behavior: new technological approaches and conservation applications. Conservation Behaviour 120, 235-244, doi: 10.1016/j. anbehav.2016.07.019.

Pearson E.L., Lowry R., Dorrian J. \& Litchfield C.A. 2014. Evaluating the conservation impact of an innovative zoobased educational campaign: 'don't palm us off' for orangutan conservation. Zoo Biology 33, 184-196, doi: 10.1002/ zoo.21120.

Putland R.L., Merchant N.D., Farcas A. \& Radford, CA. 2017. Vessel noise cuts down communication space for vocalizing fish and marine mammals. Global Change Biology 24, 1708-1721, doi: 10.1111/gcb.13996.

Ramirez K. 1999. Animal training: successful animal management through positive reinforcement. Chicago: Shedd Aquarium Press.

Ready Z.C., Flower J.E., Collins J.E., Kochin E. \& Williams C.R. 2021. Total ear canal ablation and lateral bulla osteotomy (TECA-LBO) in Atlantic harbor seals (Phoca vitulina concolor) for successful surgical management of otitis media. Journal of Zoo and Wildlife Medicine 52, 827-837, doi: 10.1638/2020-0060.

Reif J.S., Peden-Adams M.M., Romano T.A., Rice C.D., Fair P.A. \& Bossart G.D. 2009. Immune dysfunction in Atlantic bottlenose dolphins (Tursiops truncatus) with lobomycosis. Medical Mycology 47, 125-135, doi: 10.1080/13693780802178493.

Richard J.T., Dunn J.L., Romano T.A., Sartini B.L., Schmitt T.L., Haulena M. \& Vezzi N. 2016. Seasonal variation in testes size and density detected in belugas (Delphinapterus leucas) using ultrasonography. Journal of Mammalogy 98, 874-884, doi: 10.1093/jmammal/gyx032.

Richard J.T., Levine R., Romano T.A. \& Sartini B.L. 2021. Minimally invasive physiological correlates of social behaviour in belugas (Delphinapterus leucas) under human care. Polar Research 40, article no. 5504, doi: 10.33265/ polar.v40.5504.

Richard J.T., Robeck T.R., Osborn S.D., Naples L., McDermott A., LaForge R., Romano T.A. \& Sartini B.L. 2017.
Testosterone and progesterone concentrations are biologically relevant in belugas (Delphinapterus leucas). General and Comparative Endocrinology 246, 183-193, doi: 10.1016/j. ygcen.2016.12.006.

Richardson W.J. \& Wursig B. 1997. Influence of man-made noise and other human actions on cetacean behavior. Marine and Freshwater Behaviour and Physiology 29, 183-209, doi: 10.1080/10236249709379006.

Rolland R.M., Hunt K.E., Kraus S.D. \& Wasser S.K. 2005. Assessing reproductive status of right whales (Eubalaena glacialis) using fecal hormone metabolites. General and Comparative Endocrinology 142, 308-317, doi: 10.1016/j. ygcen.2005.02.002.

Romano T.A., Felten S.Y., Olschowka J.A. \& Felten D.L. 1993. A microscopic investigation of the lymphoid organs of the beluga, Delphinapterus leucas. Journal of Morphology 215, 261-287, doi: 10.1002/jmor.1052150307.

Romano T.A., Felten S.Y., Olschowka J.A. \& Felten D.L. 1994. Noradrenergic and peptidergic innervation of lymphoid organs in the beluga, Delphinapterus leucas: an anatomical link between the nervous and immune systems. Journal of Morphology 221, 243-259, doi: 10.1002/ jmor.1052210302.

Romano T.A., Keogh M.J., Schlundt C., Carder D. \& Finneran J. 2004. Anthropogenic sound and marine mammal health: measures of the nervous and immune systems before and after intense sound. Canandian Journal of Fisheries and Aquatic Sciences 61, 1124-1134, doi: 10.1139/ F04-055.

Romano T.A., Olschowka J.A., Felten S.Y., Quaranta V., Ridgway S.H. \& Felten D.L. 2002. Immune response, stress, and environment: implications for cetaceans. In C.J. Pfeiffer (ed.): Cell and molecular biology of marine mammals. Pp. 253-279. Melbourne, FL: Krieger Publishing Co.

Romano T.A., Ridgway S.H., Felten D.L. \& Quaranta V. 1999. Molecular cloning and characterization of CD4 in an aquatic mammal, the white whale, Delphinapterus leucas. Immunogenetics 49, 376-383, doi: 10.1007/s002510050510.

Romano T.A., Ridgway S.H. \& Quaranta V. 1992. MHC class II molecules on peripheral blood lymphocytes of the bottlenose dolphin, Tursiops truncatus. Journal of Experimental Zoology 263, 96-104, doi: 10.1002/jez.1402630110.

Schaffar A., Madon B., Garrigue V. \& Constantine R. 2009. Avoidance of whale watching boats by humpback whales in their main breeding ground in New Caledonia. SC/61/WW/6. Cambridge: International Whaling Commission.

Schmitt T., St. Aubin D.J., Schaeffer A. \& Dunn J.L. 2010. Baseline, diurnal variations, and stress-induced changes of stress hormones in three captive beluga whales Delphinapterus leucas. Marine Mammal Science 26, 635-647, doi: 10.1111/j.1748-7692.2009.00366.x.

Skibins J.C., Powell R.B. \& Hallo J.C. 2013. Charisma and conservation: charismatic megafauna's influence on safari and zoo tourists' pro-conservation behaviors. Biodiversity and Conservation 22, 959-982, doi: 10.1007/s10531-013-0462-z.

Spoon T.R. \& Romano T.A. 2012. Neuroimmunological response of beluga whales (Delphinapterus leucas) to translocation and a novel social environment. Brain, Behavior and Immunity 26, 122-131, doi: 10.1016/j.bbi.2011.08.003. 
St. Aubin D.J., Forney K.A., Chivers S.J, Scott M.J., Danil K., Romano T.A., Wells R. \& Gulland F.M.D. 2013. Hematological, serum and plasma chemical constituents in pantropical spotted dolphins (Stenella attenuata) following chase, encirclement, and tagging. Marine Mammal Science 29, 14-35, doi: 10.1111/j.1748-7692.2011.00536.x.

Stubberud M.W., Vindenes Y.U., Vollesta L.A, Winfield I.J., Stenseth N.C. \& Langangen O. 2019. Effects of size- and sex-selective harvesting: an integral projection model approach. Ecology and Evolution 9, 12556-12570, doi: 10.1002/ece3.5719.

Tarlow E.M. \& Blumstein D.T. 2007. Evaluating methods to quantify anthropogenic stressors on wild animals. Applied Animal Behaviour Science 102, 429-451, doi: 10.1016/j. applanim.2006.05.040.

Tausk F., Elenkov I. \& Moynihan J. 2008. Psychoneuroimmunology. Dertamatologic Therapy 21, 22-31, doi: 10.1111 / j.1529-8019.2008.00166.x.

Thompson L.A. \& Romano T.A. 2015. Beluga (Delphinapterus leucas) granulocytes and monocytes display variable responses to in vitro pressure exposures. Frontiers in Physiology 6, article no. 128, doi: 10.3389/fphys.2015.00128.

Thompson L.A. \& Romano T.A. 2016. Pressure induced changes in adaptive immune function in belugas (Delphinapterus leucas); implications for dive physiology and health. Frontiers in Physiology 7, article no. 442, doi: 10.3389/fphys.2016.00442.

Thompson L.A. \& Romano T.A. 2021. The immune response and diving: conservation considerations for belugas (Delphinapterus leucas) in a changing Arctic environment. Polar Research 40, article no. 5499, doi: 10.33265/polar. v40.5499.

Thompson L.A., Spoon T.R., Goertz C.E., Hobbs R.C. \& Romano T.A. 2014. Blow collection as a non-invasive method for measuring cortisol in the beluga (Delphinapterus leucas). PLoS One 9, el14062, doi: 10.1371/journal.pone.0114062.

Tyack P.L., Zimmer W.M.X., Moretti D., Southall B.L., Claridge D.E., Durban J.W., Clark C.W., D'Amico A., DiMarzio N., Jarvis S., McCarthy E., Morrisey R., Ward J. \& Boyd I.L. 2011. Beaked whales respond to simulated and actual navy sonar. PLoS One 6, el7009, doi: 10.1371/journal.pone.0017009.

Tyson-Moore R., Douglass D., Nollens H., Croft L. \& Wells R. 2020. Post-release monitoring of a stranded and rehabilitated short-finned pilot whale (Globicephala macrorhynchus) reveals current-assisted travel. Aquatic Mammals 46, 200214, doi: 10.1578/AM.46.2.2020.200.

Unal E., Goertz C.E.C., Hobbs R.C., Suydam R. \& Romano T. 2018. Investigation of molecular biomarkers as potential indicators of health in wild belugas (Delphinapterus leucas). Marine Biology 165, article no. 182, doi: 10.1007/ s00227-018-3439-3.

Unal E. \& Romano T.A. 2021. Of whales and genes: unraveling the physiological response to stressors in belugas (Delphinapterus leucas) at the molecular level. Journal of Zoological and Botanical Gardens 2, 559-575, doi: 10.3390/ jzbg2040040.

Vacquie-Garcia J., Lydersen C., Ims R.A. \& Kovacs K.M. 2018. Habitats and movement patterns of white whales Delphinapterus leucas in Svalbard, Norway in a changing climate. Movement Ecology 6, article no. 21, doi: 10.1186/ s40462-018-0139-z.

Van Cise A., Wade P.R., Goertz C.E., Burek-Huntington K., Parsons K.M., Clauss T., Hobbs R.C. \& Apprill A. 2020. Skin microbiome of beluga whales: spatial, temporal, and health-related dynamics. Animal Microbiome 2, article no. 39, doi: 10.1186/s42523-020-00057-1.

Vergara V., Michaud R., Moisan M., Christen D., LorenzFlammer K., Aibel S., Muzzy M., Romano T.A., Justice K. \& Sanchez S. 2019. A multi-institutional photogrammetry validation study with beluga whales under human care. Paper presented at the Second International Workshop on Beluga Whale Research and Conservation, 12-14 March, Mystic, CT, USA.

Wade P., Heide-Horgensen M.P., Shelden K., Barlow J., Carretta J., Durban J., LeDuc R., Munger L., Rankin S., Sauter A. \& Stinchcomb C. 2006. Acoustic detection and satellite -tracking leads to discovery of rare concentration of endangered North Pacific right whales. Biology Letters 2, 417-419, doi: 10.1098/rsbl.2006.0460.

Wade P.R., Reeves R.R. \& Mesnick S.L. 2012. Social and behavioural factors in cetaceans responses to overexploitation: are odontocetes less "resilient" than mysticetes? Journal of Marine Biology 2012, article no. 567276, doi: $10.1155 / 2012 / 567276$.

Watt C.A., Orr J. \& Ferguson S.H. 2016. A shift in foraging behaviour of beluga whales Delphinapterus leucas from the threatened Cumberland Sound population may reflect a changing Arctic food web. Endangered Species Research 31, 259-270, doi: 10.3354/esr00768.

Webster T., Dawson S. \& Slootem E. 2010. A simple laser photogrammetry technique for measuring Hector's dolphins (Cephalorhynchus hectori) in the field. Marine Mammal Science 26, 296-308, doi: 10.1111/j.1748-7692. 2009.00326.x.

Westen T.J. \& Larsen S.L. 2015. The Undergraduate Research Student Self-assessment (URSSA): validation for use in program evaluation. Life Science Education 14, article no. ar33, doi: 10.1187/cbe.14-11-0206. 